\title{
Evaluation of Endophytic Bacteria for Plant Growth Promotion and Pathogen Suppression Traits in Saccharum officinarum
}

\author{
Penumatsa Kishore Varma ${ }^{1}$, Kotam Vijay Krishna Kumar ${ }^{1}$, Vanapalli Chandra Sekhar ${ }^{1}$, Dandu Adilakshmi ${ }^{2}$, \\ Madugula Suresh ${ }^{1}$, Nambala Raja Kumar ${ }^{1}$, Karnam Jayachandra ${ }^{2}$ and Ravuri Anitha ${ }^{1}$ \\ 1. Department of Plant Pathology, Regional Agricultural Research Station, Anakapalle 531001, Andhra Pradesh, India \\ 2. Department of Genetics and Plant Breeding, Regional Agricultural Research Station, Anakapalle 531001, Andhra Pradesh, India
}

\begin{abstract}
Endophytes are beneficial microbes that are capable of promoting growth, besides protecting colonized plants against plant pathogens. These microbes are of either bacterial, fungal or actinomycetes in plants. In the study, the endophytic bacteria isolated from sugarcane with their characterization related to plant growth promotion and pathogen suppression have been reported. Roots, shoots and leaves of rooted tissue culture plantlets of sugarcane cultivars of 87A298 and 2009A107 were excised aseptically and isolated endophytic bacterial strains. The strains were identified using 16S rRNA gene sequence based homology. Molecular characterization of these strains was carried out for presence of antimicrobial genes. The results showed that the endophytes isolated from sugarcane tissue culture plantlets were of the genera Bacillus (B. amyloliquefaciens, B. subtilis, B. cereus, B. safensis, B. siamensis, B. aryabhattai, B. flexus and B. velezensis) and Paenibacillus pabuli. There were three antimicrobial peptides (AMPs) producing genes of bacilysin, bacillomycin and fengycin in B. amyloliquefaciens (SE1, SE7), B. siamensis (SE4, SE16), B. subtilis (SE2, SE3) and B. velezensis (SE15). The biochemical characterization assays showed that some of these strains could produce hydrogen cyanide (HCN), protease, cellulase and indole acetic acid (IAA). Few strains (SE1 and SE4) were phosphate solubilizers, whereas nine isolates were found to be diazotrophs. Most of the bacterial isolates were found antagonistic to Fusarium sacchari, the sugarcane wilt pathogen under in vitro conditions. Overall, the results suggested the scope and potentiality of sugarcane endophytic bacteria, isolated from tissue culture plantlets, in promoting plant growth and suppression of sugarcane pathogen.
\end{abstract}

Key words: Bacillus, Fusarium sacchari, Paenibacillus, antimicrobial peptides.

\section{Introduction}

Sugarcane is one of the main cash crops of India that provide sugar, besides biofuel, fibre, fertilizer and myriad of co-products with ecological sustainability. India is the second largest producer of sugar after Brazil, and accounts for $16 \%$ of world's production [1]. In Andhra Pradesh, sugarcane is grown in 1.39 lakh hectares with a production of 99.8 lakh tons. However, the sugarcane productivity (71 tons/ha) is very low compared to states, like Tamil Nadu, West Bengal, Kerala and Karnataka [2]. The productive potential of the crop is not completely harnessed due

Corresponding author: Penumatsa Kishore Varma, Ph.D., research field: plant pathology. to several biotic and abiotic factors. Among the biotic factors, diseases are the major constraints in sugarcane production, causing considerable yield losses. As majority of sugarcane diseases are sett or stalk borne and soil borne in nature, chemical management of diseases is not possible after certain crop growth stage owing to impermissible hard rind. Wilt incited by Fusarium sacchari is gaining importance in north coastal districts of Andhra Pradesh, wherever sugarcane is grown under irrigated conditions. The disease symptoms are evident in 6-8 months old plants as foliage drying followed by death of whole plant. Hence, protection needs to be offered from early stages of crop growth and should continue throughout the crop period. Inoculation of bacterial isolates with 
endophytic ability may offer continuous protection against the pathogen as they colonize sugarcane tissues effectively and suppress the pathogen colonization and thereby the disease development.

Several microbes with endophytic activity were found colonizing tissues of leaves, stalks [3] and roots of sugarcane without external sign of infection. These microbial endophytes include yeasts, fungi, bacteria and actinomycetes [4-7], with a potential for plant growth promotion and plant disease suppression. Plant growth promotion by microbial endophytes was attributed to their ability for nitrogen fixation, phosphate solubilisation, cellulase production, indole acetic acid (IAA) production, etc. [8-11]. Besides growth promotion, they were also found antagonistic to the sugarcane pathogens, viz., F. sacchari (wilt), Collectotrichum falcatum (red rot) and F. moniliforme (top rot) under laboratory conditions. Though, work has continued on sugarcane endophytes, little success has been attained on elucidating a suitable endophytic strain with both plant growth promoting ability and disease suppression. The present research aimed at identifying a potential plant growth promoting endophytic bacterial strain that promotes growth, besides managing wilt disease effectively.

\section{Materials and Methods}

\subsection{Isolation, Purification and Characterization of Endophytic Bacteria}

\subsubsection{Plant Materials}

Rooted tissue culture plantlets of sugarcane cultivars 87A298 and 2009A107 were obtained from tissue culture laboratory of Regional Agricultural Research Station (RARS), Anakapalle for isolation of endophytic bacteria.

2.1.2 Isolation and Purification of Bacterial Isolates

Leaves, stems and roots of tissue culture plantlets were separated aseptically and macerated in $1 \mathrm{~mL}$ of sterile distilled water using sterilized pestle and mortar. The homogenate was plated onto Luria Bertani agar and Bacillus agar (HiMedia) media and incubated at
$28 \pm 2{ }^{\circ} \mathrm{C}$ for $96 \mathrm{~h}$. Distinct colony types were picked up and purified through three rounds of streaking and single colony selection on Luria Bertani agar.

2.1.3 Molecular Characterization of Bacterial Isolates

The identity of the bacteria was established through 16S rRNA gene sequence based homology analysis. The genomic DNA was isolated according to Sambrook and Russel [12]. Amplification of 165 rRNA genes of bacterial isolates was carried out by PCR using universal primers, FGPS6-63-GGAGAGTTAGATCTTGGCTCAG and FGPL 132-38-CCCGGTTTCCCCATTCGG [13]. The thermocyclic conditions included initial denaturation at $95{ }^{\circ} \mathrm{C}$ for 3 min followed by 35 amplification cycles of $95^{\circ} \mathrm{C}$ for $1 \mathrm{~min}, 55^{\circ} \mathrm{C}$ for $1 \mathrm{~min}, 7{ }^{\circ} \mathrm{C}$ for 2 min followed by final extension at $72{ }^{\circ} \mathrm{C}$ for $3 \mathrm{~min}$. The PCR products were analyzed in $1 \%$ agarose gel in $1 \times$ Tris-acetate EDTA, run for $90 \mathrm{~min}$ at $100 \mathrm{~V}$, and the amplified products were excised and outsourced (BioServe Biotechnologies (India) Pvt. Ltd., Hyderabad) for partial sequencing. Similarity of $16 \mathrm{~S}$ rRNA gene sequence was aligned using BLAST Programme of GenBank database (NCBI).

\subsection{Pathogen Culture}

Wilt infected sugarcane samples were collected from agricultural farm, RARS, Anakapalle and carried to the laboratory for isolation. Infected plant tissue was disinfected and plated onto potato dextrose agar (PDA). After $5 \mathrm{~d}$ of incubation at $28 \pm 1{ }^{\circ} \mathrm{C}$, the pathogen was identified as $F$. sacchari, based on the morphology of vegetative and reproductive structures according to keys of identification [14].

\subsection{In Vitro Antagonism against F. sacchari}

The bacterial isolates were tested for antagonistic potential against $F$. sacchari, the causal agent of sugarcane wilt, by dual culture assay. An agar block (5 mm diameter) of 5-day-old culture of F. sacchari was placed in the centre of Petri plates $(90 \mathrm{~mm}$ 
diameter), containing PDA (HiMedia). A loopful of $24 \mathrm{~h}$ old culture of bacteria test antagonist was streak inoculated at either sides of $F$. sacchari disc at a distance of $2 \mathrm{~cm}$ apart. The pathogen culture was inoculated centrally on PDA plates, without bacterial streak served as control. Each treatment was replicated thrice in completely randomized design (CRD), and the inoculated plates were incubated at $28 \pm 1{ }^{\circ} \mathrm{C}$ for $5 \mathrm{~d}$ and percent inhibition was calculated [15].

\subsection{Evaluation of Endophytic Bacteria for Plant} Growth Promoting Traits

\subsubsection{Protease Activity}

All bacterial isolates were screened for protease activity by inoculating on skim milk agar plates. Plates were incubated at $28 \pm 1{ }^{\circ} \mathrm{C}$ for $72 \mathrm{~h}$ and observed for proteolysis, i.e., clear zone production around the inoculated bacterial disc.

2.4.2 Qualitative Determination of Phosphate Solubilisation

Phosphate solubilisation ability of bacterial isolates was detected by inoculating them on Pikovaskaya's agar plates [16]. The inoculated plates were incubated at $28 \pm 1{ }^{\circ} \mathrm{C}$ for $3 \mathrm{~d}$ and observed for appearance of clearing zone around the colonies.

2.4.3 Qualitative Determination of Nitrogen Fixing Ability

Nitrogen fixing ability of bacterial isolates was determined by spot inoculation of log phase culture on nitrogen free medium (Burk's medium), comprising: 10 g dextrose, $0.41 \mathrm{~g} \mathrm{KH}_{2} \mathrm{PO}_{4}, 0.52 \mathrm{~g} \mathrm{~K}_{2} \mathrm{HPO}_{4}, 0.05 \mathrm{~g}$ $\mathrm{Na}_{2} \mathrm{SO}_{4}, \quad 0.2 \mathrm{~g} \mathrm{CaCl}_{2}, 0.1 \mathrm{~g} \mathrm{MgSO}_{4}, 0.005 \mathrm{~g}$ $\mathrm{FeSO}_{4} \cdot 7 \mathrm{H}_{2} \mathrm{O}, 0.0025 \mathrm{~g} \mathrm{Na}_{2} \mathrm{MoO}_{4} \cdot 2 \mathrm{H}_{2} \mathrm{O}$ and $20 \mathrm{~g}$ agar [17]. The medium was adjusted to $\mathrm{pH}$ 7.0.

\subsubsection{Hydrogen Cyanide (HCN) Production}

HCN production was determined by modified method of Bakker and Schippers [18]. Exponentially grown cultures of bacterial isolates were streaked on to Luria-Bertani agar (LB agar) plates, supplemented with $4.4 \mathrm{~g}$ glycine/L. Simultaneously, a filter paper soaked in $0.5 \%$ picric acid in $1 \% \mathrm{Na}_{2} \mathrm{CO}_{3}$ was placed in the upper lids of each Petri plate along with uninoculated control. The plates were sealed with parafilm and incubated at $28 \pm 1{ }^{\circ} \mathrm{C}$ for $4 \mathrm{~d}$ and observed for colour change from yellow to brown for putative HCN production.

2.4.5 Qualitative Screening of Bacterial Isolates for Cellulolytic Activity

Cellulolytic activity of bacterial isolates was determined qualitatively by inoculating individual strains on to Bushnell Haas medium (BHM) agar plates amended with carboxy methyl cellulose (CMC), containing CMC $(10.0 \mathrm{~g} / \mathrm{L}), \mathrm{K}_{2} \mathrm{HPO}_{4}(1.0 \mathrm{~g} / \mathrm{L})$, $\mathrm{KH}_{2} \mathrm{PO}_{4}(1.0 \mathrm{~g} / \mathrm{L}), \mathrm{MgSO}_{4} \cdot 7 \mathrm{H}_{2} \mathrm{O}(0.2 \mathrm{~g} / \mathrm{L}), \mathrm{NH}_{4} \mathrm{NO}_{3}$ $(1.0 \mathrm{~g} / \mathrm{L}), \mathrm{FeCl}_{3} \cdot 6 \mathrm{H}_{2} \mathrm{O}(0.05 \mathrm{~g} / \mathrm{L}), \mathrm{CaCl}_{2}(0.02 \mathrm{~g} / \mathrm{L})$ and agar $(20.0 \mathrm{~g} / \mathrm{L})$. For the secretion of cellulase enzyme, CMC agar plates were incubated at $30 \pm 2{ }^{\circ} \mathrm{C}$ for $5 \mathrm{~d}$. After incubation, culture plates were flooded with $0.1 \%$ Congo red solution for $20 \mathrm{~min}$. The stain was poured off, and the plates were washed with $1 \mathrm{M}$ $\mathrm{NaCl}$ for $15 \mathrm{~min}$. A clear zone formation around the bacterial colonies indicates the hydrolysis of CMC [19].

\subsubsection{Qualitative Test for IAA Production}

A modified agar plate assay was used for qualitative estimation of IAA production by Pseudomonas isolates [20]. LB agar plate containing $100 \mu \mathrm{g} / \mathrm{mL}$ of tryptophan was prepared and poured in Petri plates. After solidification, cavities of $5 \mathrm{~mm}$ diameter and 0.2 cm depth were made by a sterile cork borer. Each cavity was filled with $50 \mu \mathrm{L}$ of overnight grown culture and incubated at $30{ }^{\circ} \mathrm{C}$ for $24 \mathrm{~h}$. After overnight growth, the cavities were filled with two drops of Salkowski reagent. The development of pink colour after addition of Salkowski reagent was considered positive for IAA production.

\subsection{Distribution of Antimicrobial Peptide (AMP) Genes in Bacterial Strains}

To study the distribution of three AMP genes (bacylisin, bacA; fengycin, fenD and bacillomycin, 
$b m y B$ ) in bacterial isolates obtained from sugarcane tissue culture plantlets, PCR was carried out in a total volume of $25 \mu \mathrm{L}$, containing $1 \times$ PCR Buffer, $1.5 \mathrm{mM}$ $\mathrm{MgCl}_{2}, 0.2 \mathrm{mM}$ dNTP, $0.2 \mu \mathrm{M}$ of each primer, $2.0 \mathrm{U}$ of Taq DNA polymerase and $2.5 \mu \mathrm{L}$ of genomic DNA. The cycling conditions for the amplification of all targets were as follows: $95^{\circ} \mathrm{C}$ for $4 \mathrm{~min}, 40$ cycles of $94^{\circ} \mathrm{C}$ for $1 \mathrm{~min}$, annealing temperature for $1 \mathrm{~min}$ and $70{ }^{\circ} \mathrm{C}$ for $1 \mathrm{~min}$. The annealing temperatures were set to $58^{\circ} \mathrm{C}$ for bacA and $f e n D, 55^{\circ} \mathrm{C}$ for bmyB [21]. The oligonucleotide primers used to detect genetic markers in bacterial endophytes are given in Table 1. Amplifications were carried out in a thermal cycler and the amplified products were analyzed in a 1.5\% agarose gel, and the gel images were captured with an imaging system.

\section{Results}

\subsection{Isolation and Identification of Endophytic} Bacteria

All bacterial isolates isolated from the tissue culture plantlets of sugarcane cultivars, 87A298 and 2009A107, were found to be gram positive, rod shaped with opaque to white and irregular edged colonies on LB agar. The endophytic bacterial isolates were identified as bacteria of the genera Bacillus and Paenibacillus by amplification of 16S rDNA genes using universal primers, FGPS 6-63 and FGPL 132-38 [13]. Comparision of $16 \mathrm{~S}$ rDNA amplified genes to sequences of GenBank has shown identity to Bacillus amyloliquefaciens (KY354250), B. subtilis (KY354251), B. cereus, B. safensis (KY354253), B. siamensis (KY354252 and KY354254), B. aryabhattai, B. flexus, B. velezensis and Paenibacillus pabuli.

\subsection{Antagonistic Activity against Fusarium sacchari}

The endophytic bacterial isolates were tested for their antagonistic activity against $F$. sacchari by dual culture method. Most of the endophytic bacteria tested have inhibited the mycelial growth of $F$. sacchari under in vitro conditions (Table 2). The highest inhibition (89.29\%) of the test pathogen was recorded with $B$. velezensis followed by $B$. subtilis SE2 and B. amyloliquefaciens SE1 with an inhibition of $87.30 \%$ and $85.91 \%$, respectively. These were followed by the endophytic bacteria B. subtilis SE3 (79.36\%), B. siamensis SE16 (75.60\%), B. amyloliquefaciens SE7 (73.41\%) and B. siamensis SE4 (70.44\%). The least inhibition of mycelia growth of $F$. sacchari was recorded with $B$. flexus (17.46\%).

\subsection{Qualitative Analysis of Endophytic Bacteria for Growth Promoting Traits}

Screening of endophytic bacteria for growth promoting traits has revealed that some of the endophytic bacterial strains could produce protease, cellulase, HCN and IAA. Few strains were found to have the ability to solubilize phosphate, and nine isolates were found to be diazotrophs. The results pertaining to biochemical characteristics of endophytic bacteria were given in Table 3.

\subsubsection{Protease Production}

Protease production was observed in $B$. amyloliquefaciens SE1, B. aryabhattai SE6, $B$. amyloliquefaciens SE7, B. cereus SE8, B. subtilis SE9 and $B$. safensis SE10, as evidenced by the production of clear halo around the inoculated bacterial colonies on skim milk agar.

Table 1 Oligonucleotide primers to detect genetic markers in Bacillus species [21].

\begin{tabular}{llll}
\hline S. No. & Primer & Expression protein & Sequence (5'-3') \\
\hline 1 & BACF & Bacylisin & CAGCTCATGGGAATGCTTTT \\
& BACR & & CTCGGTCCTGAAGGGACAAG \\
2 & FENDF & Fengycin & GGCCCGTTCTCTAAATCCAT \\
3 & FENDR & & GTCATGCTGACGAGAGCAAA \\
3 & BMYBF & Gacillomycin & GCGGGTATTGAATGCTTGTT \\
\hline
\end{tabular}


Pathogen Suppression Traits in Saccharum officinarum

Table 2 In vitro antagonism of endophytic bacterial isolates against $F$. sacchari.

\begin{tabular}{lll}
\hline S. No. & Bacterial isolate & Percent of inhibition over control (\%) ${ }^{*}$ \\
\hline 1 & B. amyloliquefaciens SE1 & $85.91(67.93)$ \\
2 & B. subtilis SE2 & $87.30(69.11)$ \\
4 & B. subtilis SE3 & $79.36(62.97)$ \\
5 & B. siamensis SE4 & $70.44(57.04)$ \\
6 & P. pabuli SE5 & $59.52(50.47)$ \\
7 & B. aryabhattai SE6 & $32.54(34.76)$ \\
8 & B. amyloliquefaciens SE7 & $73.41(58.94)$ \\
9 & B. cereus SE8 & $26.79(31.15)$ \\
10 & B. subtilis SE9 safensis SE10 & $66.67(54.72)$ \\
11 & Paenibacillus spp. SE11 & $35.53(35.36)$ \\
12 & B. megaterium SE12 & $32.34(34.64)$ \\
13 & B. aryabhattai SE13 & $29.17(32.67)$ \\
14 & B. flexus SE14 & $30.75(33.66)$ \\
15 & B. velezensis SE15 & $17.46(24.66)$ \\
16 & B. siamensis SE16 & $89.29(70.87)$ \\
\hline & Critical difference $(p=0.05)$ & $75.60(60.38)$ \\
\hline & SE(M) \pm & 1.67 \\
\hline
\end{tabular}

${ }^{*}$ Figures in parenthesis are the arc sine transformed values.

Table 3 Plant growth promoting traits of endophytic bacteria isolated from tissue culture plantlets of sugarcane.

\begin{tabular}{|c|c|c|c|c|c|c|c|}
\hline S. No. & Bacterial isolate & Protease & $\begin{array}{l}\text { Phosphate solubilizing } \\
\text { ability }\end{array}$ & $\begin{array}{l}\text { Growth on } \\
\mathrm{N} \text {-free medium }\end{array}$ & Cellulase & $\begin{array}{l}\text { HCN } \\
\text { production }\end{array}$ & $\begin{array}{l}\text { IAA } \\
\text { production }\end{array}$ \\
\hline 1 & B. amyloliquefaciens SE1 & ++ & + & + & +++ & + & - \\
\hline 2 & B. subtilis SE2 & - & - & + & - & + & + \\
\hline 3 & B. subtilis SE3 & - & - & + & - & + & + \\
\hline 4 & B. siamensis SE4 & - & + & + & - & + & - \\
\hline 5 & P. pabuli SE5 & - & - & - & - & - & - \\
\hline 6 & B. aryabhattai SE6 & + & - & - & - & - & - \\
\hline 7 & B. amyloliquefaciens SE7 & + & - & + & +++ & + & + \\
\hline 8 & B. cereus SE8 & + & - & - & - & - & - \\
\hline 9 & B. subtilis SE9 & + & - & + & - & + & + \\
\hline 10 & B. safensis SE10 & ++ & - & + & ++ & + & + \\
\hline 11 & P. pabuli SE11 & - & - & - & - & - & + \\
\hline 12 & B. megaterium SE12 & - & - & - & + & - & - \\
\hline 13 & B. aryabhattai SE13 & - & - & - & ++ & + & - \\
\hline 14 & B. flexus SE14 & - & - & - & - & - & - \\
\hline 15 & B. velezensis SE15 & - & - & + & - & + & + \\
\hline 16 & B. siamensis SE16 & - & - & + & ++ & + & - \\
\hline
\end{tabular}

+: Positive reaction; -: negative reaction.

In case of protease, phosphate solubilising and cellulose activities, the size of the halo has been denoted as,+++ and +++ based on the halo diameter (+: diameter of the halo up to $30 \mathrm{~mm},++$ : diameter of the halo from $31 \mathrm{~mm}$ to $50 \mathrm{~mm},+++$ : diameter of the halo above $50 \mathrm{~mm}$ ).

\subsubsection{Phosphate Solubilization}

Only few isolates could solubilize phosphate when inoculated on Pikovaskaya’s agar. Clear halos were produced by $B$. amyloliquefaciens SE1 and $B$. siamensis SE4; $48 \mathrm{~h}$ post inoculation onto Pikovaskaya's agar showed their ability to solubilize 
tri-calcium phosphate.

\subsubsection{Growth on N-Free Medium}

Nine endophytic bacterial isolates have shown their ability to grow on Burk's medium and were found to be free living diazotrophs. Most of the Bacillus species, viz., B. amyloliquefaciens, B. subtilis, $B$. siamensis, $B$. safensis and $B$. velezensis were found to be diazotrophs.

\subsubsection{Cellulase Production}

To indicate the cellulase activity of the endophytic bacterial isolates, diameter of clear zone around the colony on Congo red agar media was measured. A total of six bacterial isolates was found to be positive on screening media producing clear zone. $B$. amyloliquefaciens SE1 and SE7 exhibited the maximum zone of clearance around the colony with diameter of over $50 \mathrm{~mm}$. The isolates, B. safensis SE10, B. aryabhattai SE13 and B. siamensis SE16 were found to be moderate producers of cellulase with a zone of clearance between $31 \mathrm{~mm}$ and $50 \mathrm{~mm}$. However, the zone of clearance on Congo red agar was less than $30 \mathrm{~mm}$ in case of B. megaterium SE12.

\subsubsection{HCN Production}

Most of the isolates have produced HCN as evidenced by the change in the colour of filter paper from yellow to brown when grown on LB agar supplemented with glycine. HCN production was not observed in $P$. pabuli SE5, B. aryabhattai SE6, $B$. cereus SE8, Paenibacillus spp. SE11, B. megaterium SE12 and B. flexus SE14.

\subsubsection{IAA Production}

Only few isolates have produced IAA on LB agar amended with tryptophan. In agar plate assay, pink zone was observed around the cavities inoculated with the endophytic bacterial strains, B. subtilis SE2, B. subtilis SE3, B. amyloliquefaciens SE7, B. subtilis SE9, $B$. safensis SE10, Paenibacillus spp. SE11 and $B$. velezensis SE15, on addition of Salkowski reagent, indicating the ability to produce IAA in the presence of tryptophan.

\subsection{Distribution of AMP Genes}

The presence of AMP biosynthetic genes bacA, $f e n D$ and $b m y B$ was examined in 16 sugarcane endophytic bacterial isolates. The distribution of AMP genes varied among the endophytic bacteria (Table 4). The genes, bac $A$ and $b m y B$ were the most frequent genes, and the gene $f e n D$ was less frequent. The isolates containing all the three genes accounted for $43.75 \%$.

Table 4 Distribution of AMP genes in bacterial endophytes of sugarcane.

\begin{tabular}{lllll}
\hline \multirow{2}{*}{ S. No. } & Bacterial isolate & bacA & fenD & AMP genes \\
\hline 1 & B. amyloliquefaciens SE1 & - & + & + \\
2 & B. subtilis SE2 & + & + & + \\
3 & B. subtilis SE3 & + & + & + \\
4 & B. siamensis SE4 & + & - & + \\
5 & P. pabuli SE5 & - & - & + \\
6 & B. aryabhattai SE6 & + & + & + \\
7 & B. amyloliquefaciens SE7 & + & - & + \\
8 & B. cereus SE8 & + & + & + \\
9 & B. subtilis SE9 & + & - & + \\
10 & B. safensis SE10 & + & - & - \\
11 & P. pabuli SE11 & + & + & - \\
12 & B. megaterium SE12 & + & - & - \\
13 & B. aryabhattai SE13 & + & - & + \\
14 & B. flexus SE14 & + & + & + \\
15 & B. velezensis SE15 & + & + & + \\
16 & B. siamensis SE16 & + & & + \\
\hline
\end{tabular}




\section{Discussion}

In the present study, bacteria present in the tissue culture plantlets of two sugarcane clones was isolated, characterized and tested for their antagonism and plant growth promoting traits. The procedure for production of tissue culture plantlets includes extensive sterilization procedures, which are generally expected to limit the viability of microorganisms [22]. However, several bacteria were found to colonize roots, shoot and leaves of in vitro tissue culture plantlets without any deleterious effect on their growth. Several studies have proved the association of endophytic bacteria with tissue culture plantlets or embryonic suspension cultures of banana [22, 23]. The endophytic nature of the isolated bacteria was confirmed by plating the tissue culture medium (in which the tissue culture plantlets were grown) onto nutrient agar. No bacteria could be recovered from the inoculated plates.

The results showed that most of the bacteria inhabiting tissue culture plantlets of the sugarcane cultivars, 87A298 and 2009A107, are of Bacillus and Paenibacillus species. Endophytic bacteria reside within host plants without any pathogenic effects, and various endophytes have been found to functionally benefit plants by suppressing plant diseases [24]. Several Bacillus species were documented as endophytes of cotton, maize [25], banana [26] and rice [27].

In the present study, B. velezensis, B. subtilis and B. amyloliquefaciens were highly antagonistic to $F$. sacchari. The antagonistic potential of endophytic Bacillus species against Fusarium species was reported earlier. Three endophytic Bacillus species, viz., B. amyloliquefaciens, B. subtilis subsp. subtilis and $B$. thuringiensis, were found highly antagonistic to F. oxysporum f.sp. cubense, the incitant of Panama disease of banana [26]. Similarly, endophytic Bacillus species (B. cereus str. S42, B. tequilensis str. SV39, $B$. subtilis str. SV41, B. methylotrophicus str. SV44, B. amyloliquefaciens subsp. plantarum str. SV65 and $B$. mojavensis str. SV104) isolated from wild Solanaceae species (Datura metel, Solanum nigrum, $S$. elaeeagnifolium and Nicotiana glauca) were found to inhibit the mycelial growth of $F$. oxysporum f.sp. lycopercisi by $36 \%-46 \%$ [28]. The antagonistic activities of Bacillus spp. are mainly attributed to the production of hydrolytic enzymes [29], peptide antibiotics [30] and certain volatile extracellular metabolites [31].

Many isolates of Bacillus produced cyanogens in the present study and inhibited the mycelial growth of F. sacchari. Rhizobacteria are known to produce HCN and protect plants from phytopathogenic fungi [32]. HCN has been implicated in the suppression of different plant pathogens by plant growth promoting rhizobacteria (PGPR) [33, 34]. Further, IAA production by $B$. amyloliquefaciens, B. subtilis and $B$. safensis under in vitro conditions characterized them as plant growth promoting bacteria. Plant growth promotion by Bacillus species was related to the production of phytohormones, like auxins [35], gibberellins [36] and cytokinins [37]. Auxin producing $B$. subtilis strain GSV 3 recovered from groundnut rhizosphere assisted plant growth promotion [38]. In present study, some isolates of $B$. amyloliquefaciens could produce auxins and solubilize phosphate under in vitro conditions. However, the in vivo effect has to be studied under greenhouse and field conditions. Talboys et al. [39] reported increased root production in Triticum aestivum upon seed dressing with B. amyloliquefaciens strain FZB42 under low environmental phosphate concentrations.

Bacillus species synthesize various types of AMPs, which have been implicated in the biological control of several plant pathogens. Bacilysin, bacillomycin, fengycin, iturin, surfactin and subtilin are some of the AMPs elaborated by Bacillus species and are known to enhance their biocontrol efficacy, as well as fitness in plant environment [21]. Formation of pores in the cell wall and cell membranes of fungi and their subsequent disruption are one of the proposed modes 
of action of AMPs [40]. The antagonistic activity of endophytic bacteria isolated from tissue culture plantlets against $F$. sacchari may be attributed to the production of AMPs.

\section{Conclusions}

Most of the bacteria isolated from tissue culture plantlets of sugarcane are gram positive (Bacillus spp.) with an ability to produce protease, cellulase, IAA and HCN, besides their antagonistic potential against $F$. sacchari. Overall, the results of present study suggested the scope and potentiality of sugarcane endophytic bacteria, isolated from tissue culture plantlets, in promoting plant growth and suppression of sugarcane pathogens. However, extensive greenhouse and field studies are essential to utilize these endophytic bacteria for eco-friendly management of sugarcane wilt disease.

\section{References}

[1] Government of India (GOI). 2015. Price Policy for Sugarcane: 2016-17 Sugar Season. Commission for Agricultural Crops and Prices. Department of Agriculture and Cooperation, Ministry of Agriculture, Government of India, New Delhi, 80. http://cacp.dacnet.nic.in/ ViewReports. aspx?Input=2\&PageId=41\&KeyId=576.

[2] Government of India (GOI). 2017. Price Policy for Sugarcane: 2017-18 Sugar Season. Commission for Agricultural Crops and Prices. Department of Agriculture, Cooperation and Farmers Welfare, Ministry of Agriculture and Farmers Welfare, Government of India. http://cacp.dacnet.nic.in/ViewReports.aspx?Input=2\&Pag eId=41\&KeyId=595.

[3] Omarjee, J., Antwerpen, T. V., Balandreau, J., Kuniata, L., and Rutherford, S. 2004. "Isolation and Characterization of Some Endophytic Bacteria from Papau New Guinea Sugarcane.” Proc. S. Afr. Technol. Ass. 78: 189-94.

[4] Azeredo, L. A. I., Gomes, E. A. T., Mendonca-Hagler, L. C., and Hagler, A. N. 1998. "Yeast Communities Associated with Sugarcane in Campos, Rio de Janeiro, Brazil.” Internat. Microbiol. 1 (3): 205-8.

[5] Mendes, R., Pizzirani-Kleiner, A. A., Araujo, W. L., and Raaijmakers, J. M. 2007. "Diversity of Cultivated Endophytic Bacteria from Sugarcane: Genetic and Biochemical Characterization of Burkholderia cepacia Complex Isolates.” Appl. Environ. Microbiol. 73 (22): 7259-67.
[6] Favaro, L. C., Sebastianes, F. L., and Araujo, W. L. 2012. "Epicoccum nigrum P16, a Sugarcane Endophyte, Produces Antifungal Compounds and Induces Root Growth.” PLoS ONE 7 (6): e36826.

[7] Sinma, K., Nurak, T., and Khucharoenphaisan, K. 2015. "Potentiality of Endophytic Actinomycetes Isolated from Sugarcane.” KMITL Sci. Tech. J. 15 (2): 88-97.

[8] Beneduzi, A., Ambrosini, A., and Passagila, L. M. P. 2012. "Plant Growth Promoting Rhizobacteria (PGPR): Their Potential as Antagonists and Biocontrol Agents.” Genet. Mol. Biol. 35 (4): 1044-51.

[9] Muangthong, A., Youpensuk, S., and Rerkasem, B. 2015. "Isolation and Characterization of Endophytic Nitrogen Fixing Bacteria in Sugarcane.” Trop. Life Sci. Res. 26: 41-51.

[10] Tam, H. M., and Diep, C. N. 2014. "Isolation, Characterization and Identification of Endophytic Bacteria in Sugarcane (Saccharum spp. L.) Cultivated on Soils of the Dong Nai Province, Southeast of Vietnam.” Am. J. Life Sci. 2 (6): 361-8.

[11] Dong, Z., Canny, M. J., McCully, M. E., Roboredo, M. R., Cabadilla, C. F., Ortega, E., and Rodes, R. 1994. "A Nitrogen-Fixing Endophyte of Sugarcane Stems.” Plant Physiol. 105 (4): 1139-47.

[12] Sambrook, J., and Russel, D. W. 2001. Molecular Cloning: A Laboratory Manual. 3rd ed.. New York: Cold Spring Harbor Laboratory Press.

[13] Normand, P., Cournoyer, B., Simonet, P., and Nazaret, S. 1992. "Analysis of a Ribosomal RNA Operon in the Actinomycete Frankia.” Gene 111 (1): 119-24.

[14] Nelson, P. E., Toussoun, T. A., and Marasas, W. F. O. 1983. Fusarium Species: An Illustrated Manual for Identification. University Park: Pennsylvania State University Press, 193.

[15] Dennis, C., and Webster, J. 1971. "Antagonistic Properties of Species Groups of Trichoderma: III. Hyphal Interactions.” Trans. Br. Mycol. Soc. 57 (3): 363-9.

[16] Pikovaskaya, R. I. 1948. "Mobilization of Phosphorous and Soil in Connection with the Vital Activity of Some Microbial Species.” Mikrobiologii 17: 362-70.

[17] Wilson, P. W., and Knight, S. C. 1952. Experiments in Bacterial Physiology. Minneapolis, USA: Burguess, 49.

[18] Bakker, A. W., and Schippers, B. 1987. "Microbial Cyanides Production in the Rhizosphere in Relation to Potato Yield Reduction and Pseudomonas spp. Mediated Plant Growth Stimulation.” Soil Microbiol. Biochem. 19: 451-7.

[19] Emmyrafedziawati, A. K. R., and Stella, M. 2015. "Hydrolysis of Carboxy Methyl Cellulose (CMC) by Bacillus Isolated from Compost.” J. Trop. Agric. and Fd. Sc. 43 (2): 129-35.

[20] Shrivastava, U. P., and Kumar, A. 2011. “A Simple and 

Pathogen Suppression Traits in Saccharum officinarum

Rapid Plate Assay for the Screening of Indole-3-Acetic Acid (IAA) Producing Microorganisms.” Int. J. Appl. Biol. Pharm. 2 (1): 120-3.

[21] Mora, I., Cabrefiga, J., and Montesinos, E. 2011. "Antimicrobial Peptide Genes in Bacillus Strains from Plant Environments.” Int. Microbiol. 14 (4): 213-23.

[22] Thomas, P. 2004. “A Three-Step Screening Procedure for Detection of Covert and Endophytic Bacteria in Plant Tissue Cultures.” Curr. Sci. 87 (1): 67-72.

[23] Jimtha, J. C., Smitha, P. V., Anisha, C., Deepthi, T., Meekha, G., Radhakrishnan, E. K., Gayathri, G. P., and Remakanthan, A. 2014. "Isolation of Endophytic Bacteria from Embryogenic Suspension Culture of Banana and Assessment of Their Plant Growth Promoting Properties.” Plant Cell Tiss. Org. 118: 57-66.

[24] Lian, J., Wang, Z., and Zhou, S. 2008. "Response of Endophytic Bacterial Communities in Banana Tissue Culture Plantlets to Fusarium Wilt Pathogen Infection.” J. Gen. Appl. Microbiol. 54 (2): 83-92.

[25] McInroy, J. A., and Kloepper, J. W. 1995. "Survey of Indigenous Bacterial Endophytes from Cotton and Sweet Corn.” Plant Soil 173: 337-42.

[26] Souja, A., Cruz, J. C., Susa, N. R., Procopio, A. R. L., and Silva, G. F. 2014. "Endophytic Bacteria from Banana Cultivars and Their Antifungal Activity.” Genet. Mol. Res. 13 (4): 8661-70.

[27] Chung, E. J., Hossain, M. T., Khan, A., Kim, K. H., Jeon, C. O., and Chung, Y. R. 2015. "Bacillus oryzicola sp. nov., an Endophytic Bacterium Isolated from the Roots of Rice with Antimicrobial, Plant Growth Promoting, and Systemic Resistance Inducing Activities in Rice.” Plant Pathol. J. 31 (2): 152-64.

[28] Aydi Ben Abdallah, R., Jabnoun-Khiareddinen, H., Mokni-Tlilli, S., Nefzi, A., Medimagh-Saidana, S., and Daami-Remadi, M. 2015. "Endophytic Bacillus spp. from Wild Solanaceae and Their Antifungal Potential against Fusarium oxysporum f.sp. lycopercisi Elucidated Using Whole Cells, Filtrate Cultures and Organic Extracts.” J. Plant Pathol. Microbiol. 6: 324. doi:10.4172/2157-7471.1000324.

[29] Fujimoto, A., and Kupper, K. C. 2016. "Production of Antifungal Compounds and Hydrolytic Enzymes by Bacillus spp. as Mechanisms of Action against Phyllosticta citricarpa.” IOSR-JAVS 9 (11): 19-27.
[30] Mannanov, R. N., and Sattarova, R. K. 2001. “Antibiotics Produced by Bacillus Bacteria.” Chem. Nat. Compd. 37 (2): 117-23.

[31] Podile, A. R., Prasad, G. S., and Dube, H. C. 1987. "Partial Characterization of the Antagonistic Principle of Bacillus subtilis AF1.” J. Biol. Control 1: 60-5.

[32] Ahmad, F., Ahmad, I., and Khan, M. S. 2008. "Screening of Free-Living Rhizospheric Bacteria for Their Multiple Growth Promoting Activities.” Microbiol. Res. 163: 173-81.

[33] Reetha, A. K., Pavani, S. L., and Mohan, S. 2014. "Hydrogen Cyanide Production Ability by Bacterial Antagonist and Their Antibiotics Inhibition Potential on Macrophomina phaseolina (Tassi.) Gold.” Int. J. Curr. Microbiol. Appl. Sci. 3 (5): 172-8.

[34] Lanteigne, C., Gadkar, V. J., Wallon, T., Novinsack, A., and Filion, M. 2012. "Production of DAPG and HCN by LBUM300 Contributes to the Biological Control of Bacterial Canker of Tomato.” Phytopathology 102 (10): 967-73.

[35] Asghar, H., Zahir, Z., Arshad, M., and Khaliq, A. 2002. "Relationship between in Vitro Production of Auxins by Rhizobacteria and Their Growth-Promoting Activities in Brassica juncea L.” Biol. Fert. Soils 35: 231-7.

[36] Joo, G. J., Kim, Y. M., Kim, J. T., Rhee, I. K., Kim, J. H., and Lee, I. J. 2005. “Gibberellins Producing Rhizobacteria Increase Endogenous Gibberellins Content and Promote Growth of Red Peppers.” J. Microbiol. 43: 510-5.

[37] De Salamone, I. E. G., Hynes, R. K., and Nelson, L. M. 2001. "Cytokinin Production by Plant Growth Promoting Rhizobacteria and Selected Mutants.” Can. J. Microbiol. 47: 404-11.

[38] Thakur, A., and Parikh, S. C. 2015. “Auxin Hormone Production and Plant Growth Promotion by Phosphate Solubilizing Bacteria of Groundnut Rhizosphere.” Int. J. Innov. Res. Sci. Eng. Technol. 4 (9): 8539-48.

[39] Talboys, P. J., Owen, D. W., Healey, J. R., Withers, P. J., and Jones, D. L. 2014. "Auxin Secretion by $B$. amyloliquefaciens FZB42 Both Stimulates Root Exudation and Limits Phosphorous Uptake in Triticum aestivum.” BMC Plant Biol. 14 (51): 1-9.

[40] Sumi, C. D., Yang, B. W., Yeo, I. C., and Hahm, Y. T. 2015. "Antimicrobial Peptides of the Genus Bacillus: A New Era for Antibiotics.” Can. J. Microbiol. 61 (2): 93-103. 